\title{
Association between increased serum thyrotropin concentration and the oldest old: what do we know?
}

\author{
Associação entre aumento da concentração de tirotropina e longevos: \\ 0 que sabemos? \\ Glaucia Cruzes Duarte ${ }^{1}$, Maysa Seabra Cendoroglo ${ }^{1}$, Lara Miguel Quirino Araújo ${ }^{1}$, \\ Clineu de Mello Almada Filho ${ }^{1}$
}

\begin{abstract}
To assess studies that evaluate the relation between serum thyrotropin concentration, very old subjects, and their events. We searched the PubMed, SciELO, and LILACS databases for articles published between 2004 and 2012. Our search was restricted to studies involving humans aged 65 years or older, and written in English, Spanish, or Portuguese. Studies that evaluated the association between elevated serum thyrotropin concentration among elderly subjects with subclinical hypothyroidism were chosen since at least in part they included a subpopulation of individuals aged 80 years and above. Thirteen studies were selected. No significant increase in risk of cardiovascular events, coronary heart disease, or total mortality was observed. Elevated thyrotropin concentration was associated with longevity. More randomized controlled trials are required to better define the potential benefits of elevated thyrotropin concentration in this oldest old population, hormone replacement, and longevity.
\end{abstract}

Keywords: Hypothyroidism; Aged, 80 and over; Longevity

\section{RESUMO}

Avaliar os artigos que consideram a relação entre a concentração da tirotropina sérica, indivíduos muito idosos e seus eventos. Foram selecionados artigos do PubMed, SciELO e LILACS publicados entre 2004 e 2012, que consideraram uma população $\geq 65$ anos, escritos em inglês, espanhol ou português. Os estudos que avaliaram a associação entre níveis séricos elevados de tirotropina sérica e idosos com hipotireoidismo subclínico foram escolhidos, desde que incluíssem uma subpopulação com 80 anos ou mais. Treze estudos foram selecionados. Não houve associação significante entre maior risco de eventos cardiovasculares, doença coronariana ou mortalidade. A concentração elevada de tirotropina sérica foi associada à longevidade.
Mais estudos randomizados controlados são necessários para o melhor entendimento do potencial benefício da elevação de concentração da tirotropina sérica nos longevos, reposição hormonal e longevidade.

Descritores: Hipotireoidismo; Idosos de 80 anos ou mais; Longevidade

\section{INTRODUCTION}

Subclinical hypothyroidism is a laboratory diagnosis ${ }^{(1)}$ defined by an abnormally high serum thyrotropin (TSH) level associated with a normal plasma concentration of free thyroxin (fT4). ${ }^{(2-4)}$ It is common among elderly individuals and its prevalence increases with age, affecting $6 \%$ of population between 70 and 79 years and $10 \%$ of individuals above 80 years of age. ${ }^{(5,6)}$ The prevalence of subclinical hypothyroidism is lower in blacks compared with whites, in women over the age of 80 years, and in populations with iodine deficiency. ${ }^{(1)}$

Subclinical thyroid dysfunction has been associated with several negative clinical outcomes such as hypercholesterolemia, atherosclerosis, ${ }^{(7)}$ coronary heart disease events and mortality, ${ }^{(2,7)}$ cognitive impairment, ${ }^{(2,8,9)}$ depression, ${ }^{(10)}$ disability, ${ }^{(2)}$ lower physical function, ${ }^{(11)}$ and risk of progression to overt hypothyroidism. ${ }^{(12)}$

Serum TSH concentration increases slightly in very old healthy individuals, ${ }^{(13)}$ regardless of the presence of antithyroid antibodies ${ }^{(5,14)}$ and along with an agedependent decline in serum free and total triiodothyronine (T3), suggesting that some very elderly individuals

\footnotetext{
Universidade Federal de São Paulo, São Paulo, SP, Brazil.

Corresponding author: Glaucia Cruzes Duarte - Universidade Federal de São Paulo, Rua Sena Madureira, 1.500 - Vila Clementino - Zip code: $04021-021$ - São Paulo, SP, Brazil - Phone: (55 11) 5576-4840 E-mail: endocrino.draglauciaduarte@gmail.com

Received on: July 7, 2013 - Accepted on: June 28, 2014

DOI: 10.1590/\$1679-45082015RW2874
} 
may have an altered set point of the hypothalamicpituitary-thyroid axis. ${ }^{(4)}$ Despite a likely increase in serum reverse triiodothyronine (rT3) with age, ${ }^{(11)}$ free and total serum thyroxin (T4) concentrations remain unchanged, complicating the interpretation of these measurements since concomitant chronic illnesses and use of medications are often present in this population. It is possible that the decrease in thyroid function and metabolic rate ${ }^{(11)}$ may be adaptive mechanisms to prevent catabolism and reduce damage to DNA by reactive oxygen species. ${ }^{(13)}$ Furthermore, reports have demonstrated that centenarians ${ }^{(14)}$ and their offspring have higher serum TSH levels, characterizing a heritable phenotype. ${ }^{(15-17)}$

Despite this evidence, the hypothesis that some degree of physiological decrease in thyroid activity at a tissue level may favor effects in oldest old subjects remains uncertain.

\section{OBJECTIVE}

To assess studies that evaluated the relation between elevated serum thyrotropin concentrations in mild hypothyroidism and comorbidities in individuals aged over 80 years.

\section{METHODS}

This review was conducted at the Department of Geriatrics and Gerontology, Universidade Federal de São Paulo, and approved by the local Research Ethics Committee. We searched the PubMed, Scientific
Electronic Library Online (SciELO), and LILACS databases for articles published between 2004 and 2012, and performed the last survey in April 2013. To conduct the search, we used the following combinations of keywords: "subclinical hypothyroidism" OR "mild hypothyroidism" WITH "oldest old" OR "very old" OR "80 and over" or "centenarians" OR "longevity". Our search was restricted to studies involving humans aged 65 years or older, and written in English, Spanish, or Portuguese. Studies evaluating the association between elevated serum TSH levels among elderly subjects with subclinical hypothyroidism were included, since at least in part, they included a subpopulation of individuals aged 80 years and more. We excluded studies that lacked this information and studies on non-thyroidal diseases or low-T3 syndrome. Some of these studies did not exclude patients with overt hypothyroidism. We made no restrictions regarding study design or sample size.

\section{RESULTS}

Our search identified 192 studies (Figure 1).

Twenty-eight irrelevant studies were excluded for not covering the association between subclinical hypothyroidism and the oldest old $(\mathrm{n}=21)$ or not clearly considering the oldest old population $(n=9)$. Thirteen studies were selected and classified according to the Oxford Centre for Evidence-Based Medicine Levels of Evidence. ${ }^{(18)}$ Three studies were conducted in the Netherlands, ${ }^{(2,11,16)}$ one in the United Kingdom, ${ }^{(9)}$ one in Italy, ${ }^{(17)}$ four in the United States, ${ }^{(5,14,15,19)}$ and three in

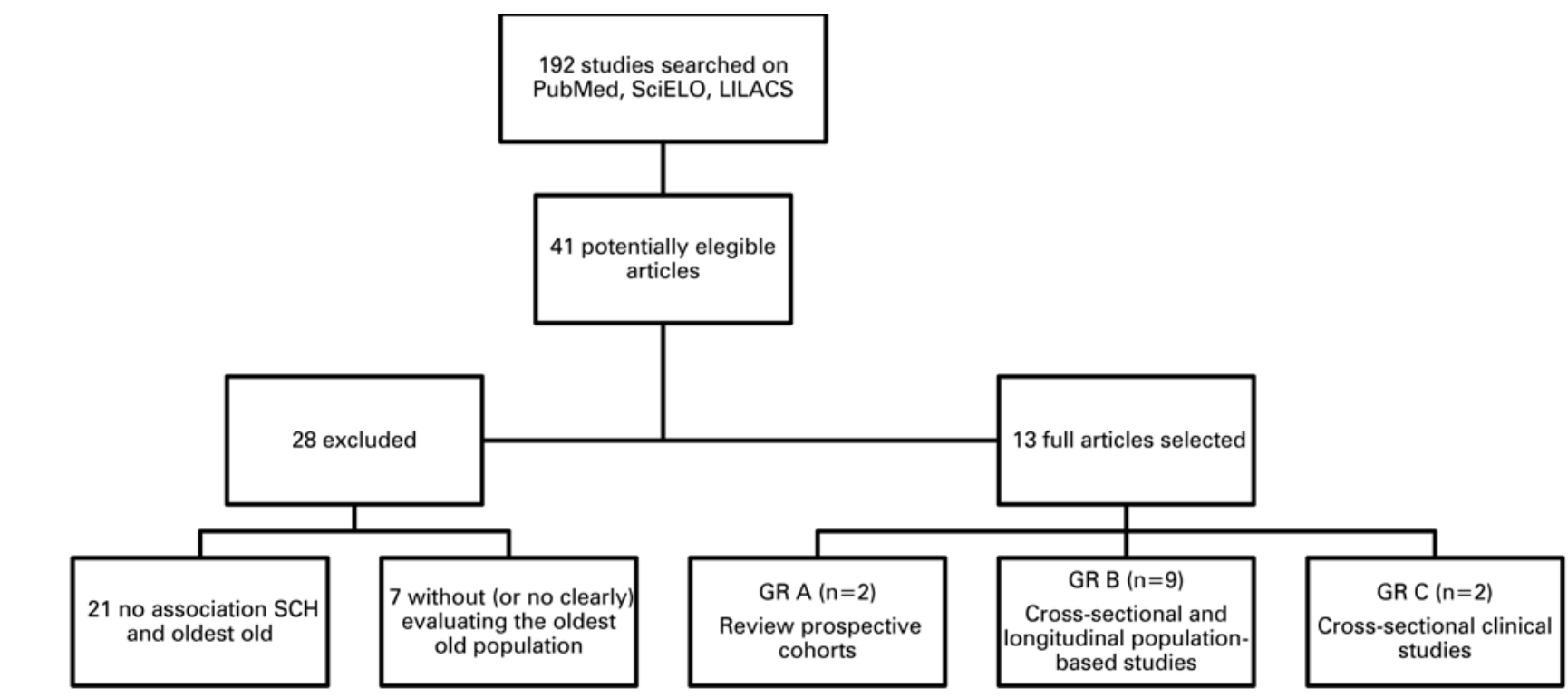

SCH: subclinical hypothyroidism; GR: level of recommendation.

Figure 1. Criteria applied for selection of the studies 
Brazil. ${ }^{(20-22)}$ One of the studies included subpopulations from various countries, ${ }^{(7)}$ (Chart 1). The total number of subjects enrolled in the studies varied from $109^{(22)}$ to 55,287 individuals. ${ }^{(7)}$ In studies that have considered the length of follow-up, the average time varied from $2^{(9)}$ to 20 years. ${ }^{(7)}$ Different reference values of TSH were adopted, with the minimum reference ranging from
0.27 to $0.5 \mathrm{mIU} / \mathrm{L}$, and the maximum ranging from 4.0 to $5.6 \mathrm{mIU} / \mathrm{L}$.

Two selected studies were multicenter trials. One was a longitudinal epidemiological study ${ }^{(9)}$ involving six centers in England and Wales evaluating the association between cognitive decline, assessed by the Mini-Mental State Examination (MMSE), and high TSH levels in

Chart 1. Studies evaluating the association between subclinical hypothyroidism and the oldest old

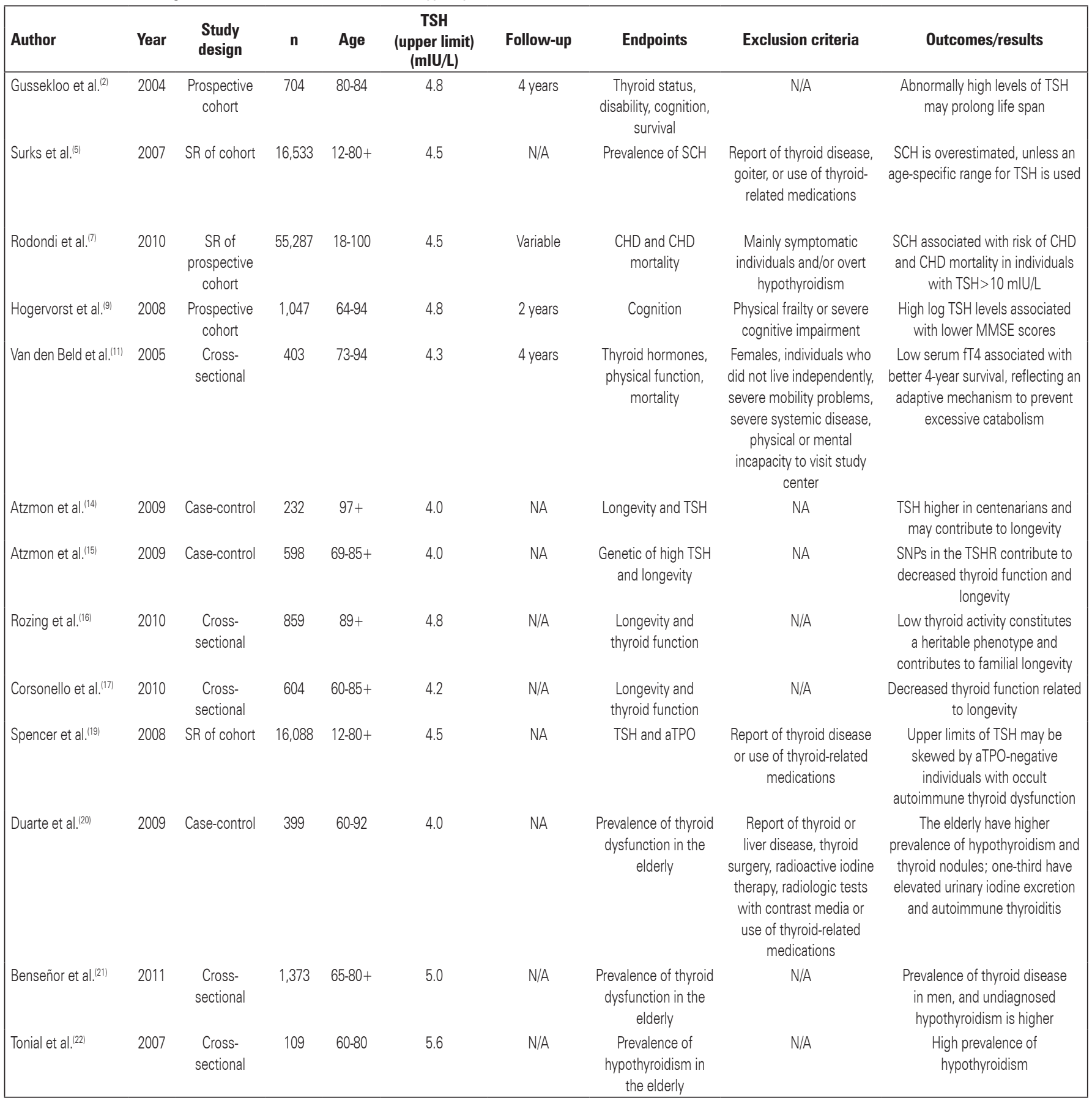

TSH: thyroid stimulating hormone; N/A: not applicable; SR: systematic review; SCH: subclinical hypothyroidism; CHD: coronary heart disease; MMSE: Mini-Mental State Examination; fT4: free thyroxin; TSHR: thyroid-stimulating hormone receptor; aTPO: antithyroperoxidase antibody; SNPs: single nucleotide polymorphisms. 
elderly individuals. The other included 11 prospective cohorts from different countries (United States, Australia, Europe, Brazil and Japan) and showed an increased risk of coronary heart disease and coronary heart disease mortality in individuals with TSH concentrations of $10 \mathrm{mIU} / \mathrm{L}$ or above. ${ }^{(7)}$ However, when the analysis included only individuals aged 80 years and more, no significant increase in risk of cardiovascular events, coronary heart disease, or total mortality was observed. ${ }^{(7)}$

Some of the cross-sectional and longitudinal populationbased studies recognized that the upper limits of serum TSH levels could have been skewed by individuals with occult autoimmune thyroid dysfunction and negative serum thyroperoxidase antibody (aTPO), ${ }^{(14)}$ whereas others considered the results to overestimate thyroid hypofunction since no age-specific range for TSH was adopted, with the possibility of identifying healthy individuals as having subclinical thyroid disease. ${ }^{(5)}$ Despite these facts, most studies confirmed that serum TSH is elevated in this population, increases gradually with age, ${ }^{(21)}$ and that this finding is very common in the population over 80 years of age. ${ }^{(14)}$ Elevated TSH was associated with longevity, especially in the oldest old, ${ }^{(2,14,19)}$ extended to family members, ${ }^{(16,17)}$ and could be correlated with better survival. ${ }^{(8)}$ Results from cross-sectional clinical studies have reported higher prevalence of both subclinical and overt hypothyroidism in oldest old subjects. ${ }^{(21-23)}$

\section{DISCUSSION}

Different studies have suggested that the thyroid gland undergoes anatomical and physiological changes with time, providing evidence that its function declines with age.

A meta-analysis demonstrated that cardiovascular events and mortality in patients with subclinical hypothyroidism were restricted to those younger than 65 years of age. ${ }^{(24,25)}$ In contrast, it showed no association between a higher risk of coronary events or mortality and elevated TSH for individuals aged 80 years or more. ${ }^{(7)}$ A possible explanation for this discrepancy may be that participants with subclinical hypothyroidism included in these studies already had preexisting comorbidity factors (such as dyslipidemia and endothelial dysfunction), or even cardiovascular disease, and by becoming exposing to more serious or fatal outcomes before the age of 80 years, increased their risks for cardiovascular events. ${ }^{(26)}$ Thus, those who survived would have a higher chance of getting old. It is unclear why inadequately high TSH would be associated with lower mortality ${ }^{(2)}$ and longevity. It is possible that a lower metabolic rate and fluctuating concentration of serum TSH may be represented by early signs of thyroid hypoechogenicity on ultrasound, ${ }^{(27,28)}$ decreased fT4, increased rT3, and altered pituitary set point, ${ }^{(14,23)}$ as has been documented in centenarians, and could possibly denote adaptive metabolic processes to prevent excessive catabolism. ${ }^{(11,23)}$ Indeed, relatives of the oldest old tended to repeat this laboratorial finding ${ }^{(16,17)}$ showing down-regulation of thyroid hormones due to genetic predisposition ${ }^{(15)}$ and benefiting from a longer life span..$^{(2,11,15,17)}$

Elderly patients with subclinical thyroid disease had worse overall results in the MMSE. The association between overt hypothyroidism and cognitive impairment is well established, and there are cases described of secondary dementia due to thyroid dysfunction. ${ }^{(9)}$ In contrast, some controversial studies have reported an inverse association between high TSH and memory function ${ }^{(9)}$ or even no association at all when considering the elderly aged over 85 years. ${ }^{(2)} \mathrm{A}$ similar observation has been made with depression. While some studies report worsening of mood with subclinical hypothyroidism, ${ }^{(10)}$ others have not confirmed this association. ${ }^{(29,30)}$

The studies selected showed no evidence that reduced thyroid function had a positive association with disability $^{(2)}$ or lower physical function. ${ }^{(11)}$

The literature lacks information on the risks of mildly elevated TSH levels on health both in the general population and in the oldest old individuals. Abnormal concentrations of TSH are often found in these elderly individuals and are associated with a prolonged life span, although the exact mechanism for that remains unclear.

Maybe the use of age-specific reference values could offer a more reliable TSH distribution, more representative of the elderly population. This could be an opportunity to redefine the upper limit of normal for serum TSH, at least for the very elderly population. ${ }^{(31)}$

Targets for TSH level during levothyroxine replacement therapy tend to be individualized and should be adjusted to around $6 \mathrm{mIU} / \mathrm{L}$ in individuals older than 70 years. ${ }^{(6)}$ Although it seems that levothyroxine replacement is unlikely to benefit and may even be harmful, ${ }^{(12,13)}$ treatment should be administered to patients considered at high risk for cardiovascular disease (diabetes mellitus, diastolic dysfunction or hypertension, atherosclerosis, smokers) with $\mathrm{TSH}$ greater than $10 \mathrm{mIU} / \mathrm{L}$ and to those with antithyroid antibodies and/or positive ultrasound findings who may progress to overt hypothyroidism. ${ }^{(6,12,32)}$

\section{CONCLUSION}

Current clinical implications and treatment recommendations for oldest old individuals with subclinical hypothyroidism are still unclear. With the gradual expansion of the 
age group of very old individuals, more randomized controlled trials are required to better define the potential benefits of thyroid hormone replacement for this population.

\section{REFERENCES}

1. Peeters RP. Thyroid hormones and aging. Hormones (Athens). 2008;7(1):28-35. Review.

2. Gussekloo J, van Exel E, Craen AJ, Meinders AE, Frölich M, Western RG. Thyroid status, disability and cognitive function and survival in old age. JAMA. 2004;292(21):2591-9.

3. Brabant G, Beck-Peccoz P, Jarzab B, Laurberg P, Orgiazzi J, Szabolcs I, et al. Is there a need to redefine the upper normal limit of TSH? Eur J Endocrinol. 2006;154(5):633-7. Review.

4. Laurberg P, Andersen S, Carlé A, Karmisholt J, Knudsen N, Pedersen IB. The TSH upper reference limit: where are we at? Nat Rev Endocrinol. 2011;7(4):232-9. Review.

5. Surks MI, Hollowell JG. Age specific distribution of serum thyrotropin and antithyroid antibodies in the US population: implications for the prevalence of subclinical hypothyroidism. J Clin Endocrinol Metab. 2007;92(12):4575-82.

6. Biondi B. Should we treat all subjects with subclinical thyroid disease the same way? Eur J Endocrinol. 2008;159(3):343-5.

7. Rodondi N, den Elzen WP, Bauer DC, Cappola AR, Razvi S, Walsh JP, Asvold BO, lervasi G, Imaizumi M, Collet TH, Bremner A, Maisonneuve P, Sgarbi JA, Khaw KT, Vanderpump MP, Newman AB, Cornuz J, Franklyn JA, Westendorp RG, Vittinghoff E, Gussekloo J; Thyroid Studies Collaboration. Subclinical hypothyroidism and the risk of coronary heart disease and mortality. JAMA. 2010;304(12):1365-74.

8. Parle J, Roberts L, Wilson S, Pattison H, Roalfe A, Haque MS, et al. A randomized controlled trial of the effect of thyroxin replacement on cognitive function in community-living elderly subjects with subclinical hypothyroidism: the Birmingham Elderly Thyroid study. J Clin Endocrinol Metab. 2010;95(8):3623-32.

9. Hogervorst E, Huppert F, Matthews FE, Brayne C. Thyroid function and cognitive decline in the MRC Cognitive Function and Ageing Study. Psychoneuroendocrinology. 2008;33(7):1013-22.

10. Chueire VB, Romaldini JH, Ward L. Subclinical hypothyroidism increases the risk for depression in the elderly. Arch Gerontol Geriatr. 2007;44(1):21-8.

11. Van den Beld A, Visser TJ, Feelders RA, Grobbee DE, Lamberts SW. Thyroid hormone concentrations, disease, physical function and mortality in elderly men. J Clin Endocrinol Metab. 2005;90(12):6403-9.

12. Biondi $B$, Cooper DS. The clinical significance of subclinical thyroid dysfunction. Endocr Rev. 2008;29(1):76-131. Review.

13. Peeters RP. Thyroid function and longevity: new insights into an old dilemma. J Clin Endocrinol Metab. 2009;94(12):4658-60.

14. Atzmon G, Barzilai N, Hollowell JG, Surks MI, Gabriely I. Extreme longevity is associated with increased serum thyrotropin. J Clin Endocrinol Metab. 2009;94(4):1251-4.

15. Aztmon G, Barzilai N, Surks MI, Gabriely I. Genetic predisposition to elevated serum thyrotropin is associated with exceptional longevity. J Clin Endocrinol Metab. 2009;94(12):4768-75.

16. Rozing MP, Houwing-Duistermaat JJ, Slagboom PE, Beekman M, Frölich M, de Craen AJ, et al. Familial longevity is associated with decreased thyroid function. J Clin Endocrinol Metab. 2010;95(11):4979-84.
17. Corsonello A, Montesanto A, Berardelli M, De Rango F, Dato S, Mari V, et al. A cross-section analysis of FT3 age-related changes in a group of old and oldest-old subjects, including centenarians' relatives, shows that a down-regulated thyroid function has a familial component and is related to longevity. Age Ageing. 2010;39(6):723-7.

18. Phillips B, Ball C, Sackett D, Badenoch D, Straus S, Haynes S, et al. Oxford Centre for Evidence-based Medicine - Levels of Evidence (March 2009). Nuffield Department of Primary Care Health Sciences; 2009 Available from: http://www.cebm.net/index.aspx?0=1025

19. Spencer CA, Hollowell JG, Kazarosyan M, Braverman LE. National Health and Nutrition Examination Survey III thyroid-stimulating hormone (TSH)thyroperoxidase antibody relationships demonstrate that TSH upper reference limits may be skewed by occult thyroid dysfunction. J Clin Endocrinol Metab. 2007;92(11):4236-40.

20. Duarte GC, Tomimori EK, Camargo RY, Rubio IG, Wajngarten M, Rodrigues AG, et al. The prevalence of thyroid dysfunction in elderly cardiology patients with mild excessive iodine intake in the urban area of São Paulo. Clinics. 2009;64 (2):135-42

21. Benseñor IM, Goulart AC, Lotufo PA, Menezes PR, Scazufca M. Prevalence of thyroid disorders among older people: results from the São Paulo Ageing \& Health Study. Cad. Saúde Pública. 2011;27(1):155-61.

22. Tonial R, Rosa LA, Rosa MI, Basso FO, Argente JS. Prevalência de hipotireoidismo em residentes das seis instituições para idosos do município de Criciúma - SC. Arq Catarinenses Med. 2007;36(4):37-41.

23. Mooradian AD. Subclinical hypothyroidism in the elderly: to treat or not to treat? Am J Ther. 2011;18(6):477-86

24. Ochs N, Auer R, Bauer DC, Nanchen D, Gussekloo J, Cornuz J, et al. Metaanalysis: subclinical thyroid dysfunction and the risk for coronary heart disease and mortality. Ann Intern Med. 2008;148(11):832-45.

25. Razvi S, Shakoor A, Vanderpump M, Weaver JU, Pearce SH. The influence of age on relationship between subclinical hypothyroidism and ischemic heart disease: a meta-analysis. J Clin Endocrinol. Metab. 2008;93(8):2998-3007.

26. Mariotti S. Mild hypothyroidism and ischemic heart disease: is age the answer? J Clin Endocrinol Metab. 2008;93(8):2969-71.

27. Rosário PW, Bessa B, Valadão MM, Purisch S. Natural history of mild subclinical hypothyroidism: prognostic value of ultrasound. Thyroid. 2009;19(1):9-12.

28. Shin DY, Kim EK, Lee EJ. Role of ultrasonography in outcome prediction in subclinical hypothyroid patients treated with levothyroxine. Endocr J. 2010; 57(1):15-22.

29. Kim JM, Stewart R, Kim SY, Bae KY, Yang SJ, Kim SW, et al. Thyroid stimulating hormone, cognitive impairment and depression in an older Korean population. Psychiatry Investig. 2010;7(4):264-9.

30. Freitas AC, Campolina AG, Ribeiro RL, Kitadai FT. Comparação de função cognitiva e depressão em pacientes hipotiroideos subclínicos com eutiroidianos e hipotiroideos em tratamento, acima de 65 anos. Rev Bras Clin Med. 2009;7:89-94.

31. Boucai L, Hollowell JG, Surks Ml. An approach for development of age-, gender-, and ethnicity-specific thyrotropin reference limits. Thyroid. 2011;21(1):5-11.

32. Sgarbi JA, Teixeira PF, Maciel LM, Mazeto GM, Vaisman M, Montenegro Junior RM, et al. Consenso brasileiro para abordagem clínica e tratamento do hipotiroidismo subclínico em adultos: recomendações do Departamento de Tireoide da Sociedade Brasileira de Endocrinologia e Metabologia. Arq Bras Endocrinol Metab. 2013;57(3):166-83. 